
\title{
$\begin{array}{ll}\text { Research Square } & \begin{array}{l}\text { Preprints are preliminary reports that have not undergone peer review. } \\ \text { They should not be considered conclusive, used to inform clinical practice, } \\ \text { or referenced by the media as validated information. }\end{array}\end{array}$
}

\section{Violence Against Children and Associated Factors Among High School Students in Jimma Town}

\section{Fanta Asefa Disasa}

Jimma University College of Public Health and Medical Sciences

Yibeltal Siraneh Belete

Jimma University College of Public Health and Medical Sciences

Yesuf Ahmed Aragaw

Jimma University College of Public Health and Medical Sciences

Abraraw Tesfaye Wold

Jimma University College of Education: Jimma University College of Natural Sciences

Abonesh Taye Kumsa ( $\nabla$ aboneshtaye96@gmail.com )

Jimma University College of Public Health and Medical Sciences https://orcid.org/0000-0003-3588-3387

\section{Research}

Keywords: Physical violence, psychological violence, perpetrators, prevention mechanism, parents or guardians, Victims

Posted Date: October 2nd, 2020

DOI: https://doi.org/10.21203/rs.3.rs-83277/v1

License: (1) (i) This work is licensed under a Creative Commons Attribution 4.0 International License. Read Full License 


\section{Abstract}

Experiencing violence in childhood impacts lifelong health and well-being. Yet being subject to violence at a young age causes enduring psychological, social and neurological vandalism which stops people reaching their full potential in life. Violence against children includes all forms of violence against people under 18 years old ; therefore the purpose of this study is to determine the magnitude of violence against children and associated factors among sampled high school students in Jimma town.

Method: Institution based crossectional study was employed among sampled 423 private and public high school students of Jimma town from february15-30, 2018. Self-administered structured questionnaire was used to collect the data. A multi stage with proportional to sample size was employed.

Result: A total of 419 respondents participated in the study, making the response rate $99 \%$. A large proportion of the study subjects, $57.5 \%$, were females, and $56.3 \%$ were Oromo's. The study indicates that the prevalence of violence among high school children's' in Jimma town is $62.5 \%$. Children who had faced severe physical violence accounted for $14.1 \%$. Pertaining to parental relationships and interactions, the majority of the school children (66.3\%) did not have free discussion on reproductive health issues with their parents or guardians.

Conclusion: The prevalence of any form of violence in life time (Physical, sexual and psychological) found to be high. Of all children who experienced violence near to half of them encountered mild physical violence. Less number of school children had experience of Kchat chewing and/or alcohol use.

\section{Background}

Violence against children is extensively accepted and considered a natural part of life. Yet being subject to violence at a young age causes enduring psychological, social and neurological vandalism which stops people reaching their full potential in life. The effects reach further, with lifelong social and economic costs to the country ${ }^{(1)}$.

Violence against children cuts across border of geography, race, class, religion and culture. It happens in homes, schools and streets in places of work and entertainment, and in care and detention centers. The executioners include parents, family members, teachers, caretakers, law enforcement authorities and other children. Some children are particularly vulnerable because of gender, race, ethnic origin, disability or social status. And no country is immune, whether rich or poor ${ }^{(2)}$.

Violence against children is massively underestimated and the government isn't doing nearly enough. In large Violence against children point to uneven power relationship in different forms and manifestations involving economic status, social status, physical and mental status, gender roles, cultural and religious mores. Where there is inequality and discrimination, there is violence against children (VAC) which can be an extreme form of discrimination. Violence against children can have three forms such as physical, psychological or sexual ${ }^{(3)}$.

World health organization identified violence against children as a growing public-health issue with a global magnitude and quantifies the epidemiological global health burden of violence as mortality is only a tip of the ice berg thus, 1.66 million violence related deaths $(28.8 / 100,000)$ universally was reported 520,000 Homicides, 815,000 Suicides, 310,000 War-related. Of these 1.66 million deaths: 1.51 is from low and middle income 
countries $(32.1 / 100,000)$ and the rest 0.15 is from High-income countries $(14.4 / 100,000$ and for the morbidity or nonfatal violence related epidemiologic figure Stress and psychological impacts, Loss of work, potential and quality of life Physical injury not requiring medical care and Culturally "acceptable" violent acts are reported (4).

Reports from national and international organization working on child protection elaborate that Violence against children in Ethiopia is widespread. A 2005 study by Save the Children and the African Child Policy Forum (ACPF) on corporal punishment found that among 1873 children aged 4 to 18 years old, nearly threequarters report being hit with a stick or an open hand, two-thirds reported being whipped, and nearly a third reported being punched. Children universally report experiencing some kind of emotional violence, typically in the form of insults, shouting and threats ${ }^{(5)}$.

The finding of the study conducted in Jimma zone Limmu Genet High school on sexual abuse among adolescents indicated that sexual assault is prevalent which means $1 / 3 \mathrm{rd}$ of the adolescents $31.9 \%$ were sexually assaulted in the schools and the common sexual harassment in the school was verbal sexual harassment, but these study fails to identify the perpetuators of the action ${ }^{(6)}$.

Young Lives qualitative data in Ethiopia show that $90 \%$ of children and young people interviewed $(n=60$, age range 7-20 years) have experienced some kind of violence, while survey data show that by age 8 , over onethird $(38 \%)$ of children have experienced corporal punishment in school ${ }^{(6)}$.

Factors influencing violence against children can be social (Rapid social change, Gender, social and economic inequalities, Weak economic safety nets, Poor rule of low, Cultural norms that support violence), community (Poverty, High unemployment, High crime level, Local illicit drug trade, High residential mobility, situational factors), relationship (Poor parenting practices, Marital discord, Violent parental conflict, Low socio economic house hold status, Friends that engage in violence) and individual related (Victim of child maltreatment, Psychological or personality disorder, Alcohols or substance abuse, history of violent behavior) factors $(7)$. Children can also be affected by two other types of violence that are: self-directed violence, including suicidal behavior and self-abuse, and collective violence such as war and terrorism, committed by larger groups of people, human/child trafficking. In addition, a risk factor that in some settings may increase the likelihood of violence against children ${ }^{(7)}$.

According to report from UNICEF on Global Statistics on children's Protection from Violence, exploitation and abuse, the violent groups are individuals, children's, community and minority groups. The report underlines that precipitating factors such as war, robbery, mental illness and contributing factors like drug and alcohol, poverty culture, emotions and psychosis are the magnificent factors. The impact of the violence against children on different social and economic wings are also not undermined and resulted on death/ disability, economic mental illness. Millions of children worldwide experience the worst kinds of rights violations. Millions more children, not yet victims, are inadequately protected against them ${ }^{(8)}$.

However, the prevalence, forms or types, sources, preventive mechanisms and factors associated with violence against children in Jimma Town is not studied and clear yet. Hence, the objective of this study was to assess the prevalence, and associated factors of violence against children among high school students in Jimma Town. 


\section{Methods And Participants}

\section{Study area and Design}

The study has been conducted in Jimma Town public and private secondary (high) schools from february1530, 2018. Jimma is located $356 \mathrm{~km}$ south-west of Addis Ababa. The town has estimated population of 192,000, and there are four public secondary schools (Abba Buna, Jiren, Saxoo, and Jimma University Community), and six private secondary schools (Eldan, Catholic, Beteseb, Tesfa Tewahido, Ebifam, and Mowada). Jimma is the largest town in south-western Ethiopia, situated in Oromia Region in Jimma Zone. The study has been conducted in selected public and private secondary schools. The study has employed school based cross sectional study design. All public and private secondary schools found in Jimma Town comprise the source population. The study population consists of three public and two private schools from Jimma Town.

Secondary school students whose age is under 18 years were included since they are considered as children in Ethiopia, considering proportional number of girls and boys from each school and grade.

\section{Sample size determination and sampling procedure}

Using single population proportion formula, assuming 50\% prevalence of violence against children, $95 \%$ confidence level, and $5 \%$ marginal error and by adding $10 \%$ of non-response rate, the sample size was 423 . The survey has been conducted on randomly selected two private and three public secondary schools. A multi stage with proportional to sample size was employed considering type of school, students school grade and class section. From each selected section, students were randomly (lottery method) taken using students registration book by considering sex proportion.

\section{Data collection tools}

Self-administered structured questionnaire was used to collect the data which had five parts such as sociodemographic characteristics of the child and parents, prevalence with forms of violence, child's history of substance uses and the attributes of family behaviors, perpetrators of violence against children and related variables, and existing prevention mechanisms. The questionnaire was initially prepared in English and then translated into two local languages such as Amharic and Afaan Oromo. The questionnaire passed through a three-phase review process. In the first phase, teachers and school staff reviewed the items; in phase 2, the research team tested the items on $5 \%$ a sample in primary schools in Seka Town to check the understanding of the students and finally, the modified version of the questionnaire were duplicated and administered to 423 secondary school students in each selected sections within the class room.

\section{Method of Data Analysis}

Data were checked for completeness, consistency and entered into Epi Data version 3.1. SPSS version 21.0 was used for statistical analysis after cleaning. A logistic regression model was used to identify explanatory variables. Candidate variables at $p$ - value $<0.25$, in bivariate analysis, were entered into multiple logistic regressions. Binary logistic regression analysis used to see the values of COR which was declared as significant at p-value $<0.05$. Backward model selection method was used. The degree of association between dependent and independent variables were assessed using an adjusted OR with 95\% Cl. The Hosmer and Lemeshow test were used to check model fitness at P-value of 0.05. 


\section{Result And Discussion}

\section{Socio-demographic characteristics}

A total of 419 respondents participated in the study, making the response rate $99 \%$. A large proportion of the study subjects, $57.5 \%$, were females, and $56.3 \%$ were Oromo's. Nearly half, $50.4 \%$ of the study participants were followers of Orthodox Christianity. In terms of residence, almost of the respondents, $93.6 \%$, were from Jimma Town. Similarly, most of the study subjects (92.6\%) fell in the age range of $15-19$ years while the rest $(7.4 \%)$ fell in the younger age category of 10-14 years. In terms of educational status, $53.9 \%$ of the respondents were attending grade 9 while $46.1 \%$ were from grade 10. Most of the respondents (93.6\%) were residents of Jimma Town, whereas only 6.4 came from outside the town. Findings related to educational performance indicate that $31.5 \%$ had very good result followed by who had good result, accounting for $21.7 \%$. Respondents with satisfactory and poor educational performance accounted for 17.7 and $3.6 \%$ respectively. Regarding marital status or sexual relationships, the study has shown that a large majority $(72.1 \%)$ were single, followed by those students who had boyfriend or girlfriend, accounting for (22.4\%). Married students and co-ha biting ones accounted for 4.1 and $1.4 \%$ respectively. The other important socio-demographic characteristics investigated were parental relationships and status. Accordingly, large majorities (77.8\%) were from married and living together family, while respondents from broken families due to divorce and deceased partner accounted for $11.2 \%$ and $8.15 \%$ respectively. Respondents with orphan status accounted for $2.9 \%$. In terms of parental educational status, the findings show that a large majority (82.6\%) had literate father, while only $6.2 \%$ had illiterate father. Among the literate fathers, 38.25 had attained above grade 12. Those who attained grades 11 to 12,9 to 10 and 1 to 8 accounted for $22.8,22.5$, and $16.5 \%$ respectively. Similarly, a large majority (82.6\%) had literate mothers whereas only $8.1 \%$ had illiterate mothers. Among the literate mothers, a large proportion (46.5\%) attained grades 9 to 10 , followed by those who attained grades 1 to 8 , accounting for $21.4 \%$. Those mothers who attained above grade 12 and 11 to 12 grades accounted for 20.5 and $11.6 \%$ respectively. Regarding provision of money for basic needs, a large majority (73.7\%) reported that they got it, while $26.3 \%$ reported lack of such support. (See Table 1)

\section{The prevalence of violence against children}

The study indicates that 262 or $62.5 \%$ of the school children living in Jimma Town had experienced some form of violence in their life; $12.9 \%, 7.9 \%, 46.5 \%$ encountered mild sexual violence, severe sexual violence and mild physical violence respectively. Children who had faced severe physical violence accounted for $14.1 \%$. Respondents' who had encountered emotional or psychological violence accounted for $37 \%$. (See Table 2)

\section{Children history of substance use and the attributes of family behaviors}

Pertaining to parental relationships and interactions, the majority of the school children (66.3\%) did not have free discussion on reproductive health issues with their parents or guardians. As to the level of family control, a little bit more than half of the respondents (51.6\%), $42 \%$ and $6.4 \%$ experienced tight, moderate and loose family control. The majority $(72.6 \%)$ did not witness parental conflict at home. With regard to substance use, the study has shown that most of the school children (88.8\%) did not chew Chat. Similarly, most of the respondents (94\%) did not smoke cigarettes at all. A large majority $82.3 \%$ ) had never consumed alcohol while $17.7 \%$ of the 
respondents had already used alcohol. The use of illegal drugs such as hashish and marijuana was even more restricted among school children as $95.2 \%$ did not use it at all.(Table 3 )

\section{Perpetrators of Violence against Children and Related Variables}

Alarmingly enough, the three highest perpetrators of physical violence against children were found to be boyfriend/girlfriend, teachers, and family members, accounting for 28.3, 23.3 and 22.2 respectively. With regard to emotional or psychological violence, the leading perpetrators were teachers, boyfriend/girlfriend and family members, accounting for $38 \%, 21.4$, and 16.7 respectively. Similarly, the highest perpetrators of sexual violence were boyfriend/girlfriend, teachers, and family members, accounting for $35.3 \%, 25.9 \%$ and $14.4 \%$ respectively. A large proportion of the violence against children (41\%) occurred during the daytime, while $28 \%$ was perpetrated at night. Regarding spots of violence, school, streets and home account for $34.5 \%, 32.5 \%$ and $24 \%$, respectively. The majority of school children (66.5\%) put the blame on the perpetrators of violence, while $15 \%$ and $14.5 \%$ took the blame themselves and attributed it to the community, respectively. Gender difference was not considered important in exposing children to violence by $58 \%$ of the respondents. Regarding the interpersonal relationships between the school children and their parents/guardians, $58.9 \%$ had positive interactions most of the time; $64.7 \%$ always accepted and followed their advice and guidance, while $16.9 \%$ sometimes rejected them. The majority (65.2\%) always had positive and smooth interactions with their school teachers; only $9.8 \%$ had negative and rocky relationships. (See Table 4)

\section{Existing prevention mechanisms of violence}

In terms of awareness, the majority (69.2\%) claimed to have known some mechanisms that would protect them from violence. The three most important mechanisms included being disciplined and respectful to others; knowing where, with whom and when to move; and knowing the behavior of other person before establishing close relationships,accounting for $39.3 \%, 25.9 \%$, and $23.8 \%$, respectively. As first res ponders, $48.4 \%$ mentioned family members, while any person in the nearby and friends were mentioned by $18.1 \%$ and $15.5 \%$, respectively. A large proportion (57.3\%) depended on strict rules and regulations to be protected from violence at school, followed by parents and teacher's committee, mentioned by $20 \%$ of the respondents. In residential areas, $49.9 \%$, $25.1 \%$ and $21.7 \%$ sought guarantee from patrolling police, community leaders and Kebele militia force, respectively. A large majority (81.6\%) indicated that they had obtained advice from their parents or guardians as to how they could protect themselves from violence. (See table 5)

\section{Factors Associated with Violence}

First, bi variate logistic regressions were done to identify candidate variables. From this step, 14 variables were subjected to be candidate using $\mathrm{P}$-value of $<0.25$. Those were parental relationship $(\mathrm{P}-0.005)$, gender $(\mathrm{P}-0.076)$, child's achievement ( $P-0.116)$, mother's educational status ( $P-0.171)$, father's educational status ( $P-0.001)$, witnessing parental conflict (P-0.001), family control (P-0.050), Ever Kchat chewing (P-0.001), ever drunk alcohol (P-0.000), interaction with parents/guardian ( $\mathrm{P}-0.001)$, reaction to parents advice (P-0.003), interaction with teachers (P-0.131), money gift from family ( $P-0.001)$, and educational status of the child (grade) (P-0.176). Out of these candidates, only five variables were become independent and significantly associated factors that affect occurrence of violence among school children. Those were fathers' educational status (P-0.021), money 
gift from family (P-0.005), witnessing parental conflict (P-0.007), ever drunk any alcohol (P-0.034), and interaction with parents (P-0.006).

In the multi-variable logistic regression analysis; father's educational status, money gift from the family, witnessing family conflict, ever drunk alcohol and interaction with parents were independent predictors of violence against children. The odds of being experiencing violence among children borne from illiterate fathers was three times more likely than children born from literate fathers [AOR=2.827, 95\% Cl: $(1.173,6.814)]$. Children who did not have access to money as a gift from family were two times more likely to be exposed for violence than their counterparts [AOR=2.345,95\% Cl:(1.297,4.239)]. Children who witnessed family conflict in the home had $54 \%$ of probability to face violence than their counterparts [AOR=0.465, 95\% Cl: $(0.266,0.813)]$. In the other hand, children who ever drunk alcohol had $53 \%$ of probability to experience violence than their counterparts $[\mathrm{AOR}=0.476, \mathrm{Cl}:(0.234,0.945)]$. More over, children who occasional disagreed and quarreled with their family or guardian had $61 \%$ of probability to be violated than those most of the time had positive interactions [AOR=0.393, 95\% Cl: $(0.201,0.768)]$.(See Table 6)

\section{Discussion}

Violence against children remains a pervasive, but largely ignored issue in many parts of the world, particularly in Africa. This is certainly the case in Ethiopia, where children regularly face humiliating physical punishment, sexual violence and psychological abuse at home, in school and in the community-at-large. This study assessed the prevalence and associated factors of violence among 419 high school students in Jimma Town, Ethiopia. The prevalence of any form of violence (Physical, sexual and psychological) found to be $62.5 \%$. This finding is consistent with studies conducted in Ambo and Jimma, and Northern Nigeria ${ }^{(9-11)}$.

This high level of prevalence might be due to the sensitivity of our measuring item which was "did you face any form of violence in your life?" This includes any type/forms of violence encountered in life and very wide to accommodate from mild to severe violence in each forms.

Among the students who experienced violence, 12.9\%, 7.9\%, 46.5\% encountered mild sexual violence (rape), severe sexual violence (rape) and mild physical violence respectively. This finding is lower than studies conducted in other African countries; the life time prevalence of sexual violence (rape) in South West Nigeria and Urban Zimbabwe was $42.1 \%$ and $33 \%$ respectively $(12,13)$.

This discrepancy might be due to social and cultural variation between the study subjects in reporting sexual violence or rape. In Ethiopian context, sexual related offence particularly rape is a strong cultural norm including abduction. Moreover; the chance of engaging in marriage is considered as minimal for the female rape survivor afterwards. Surprisingly, there were also male children faced sexual violence that indicates there is a practice of homosexuality. However, they might keep secret for fear of the stigma and other negative responses from the community. From those points of view, under reporting might be in our context in both sex.

Pertaining to parental relationships and interactions, the majority of the school children (66.3\%) did not have free discussion on reproductive health issues with their parents or guardians. As to the level of family control, a little bit more than half of the respondents (51.6\%), $42 \%$ and $6.4 \%$ experienced tight, moderate and loose family control. Tighter control over the children without free discussion will be one of the pushing factors that could 
expose them for different forms of violence. Moreover, less disclosure of RH issues may be associated with lack of social support, and hence higher likelihood of violence will happen. In addition, witnessing family violence may increase the likelihood of later victimization to any forms of violence especially for sexual violence. This could be explained by learning and acceptance of the victim's role of the early abusive environment ${ }^{(14-15)}$.

With regard to substance use, the study has shown less number of school children (11.2\%) had experience of kchat chewing. Less than one fifth $(17.7 \%)$ of the respondents had already used alcohol. This finding is lower than the magnitude reported from Jimma Zone Limu Genet district. This might be due to children under 18 years only included to our study. They may consider it as sensitive issue and may not provide their actual experience; student's willingness in giving genuine information might underestimate the magnitude of the problem and social desirability bias may also affect it $(6,16)$.

The common perpetrators of physical violence against children were found to be boyfriend/girlfriend, teachers, and family members, accounting for $28.3,23.3$ and 22.2 respectively. With regard to emotional or psychological violence, the leading perpetrators were teachers, boyfriend/girlfriend and family members, accounting for $38 \%$, 21.4 , and 16.7 respectively. Similarly, the highest perpetrators of sexual violence were boyfriend/girlfriend, teachers, and family members, accounting for $35.3 \%, 25.9 \%$ and $14.4 \%$ respectively. This finding is consistent with studies conducted among school students in Addis Ababa, Jimma, and Tanzania that reported greater number of respondents were perpetrated by someone they closely knew and the most common perpetrators were found to be friends, teachers, peers and close relatives ${ }^{(17-20)}$.

Near to half of the respondents encountered violence (41\%) that occurred during the daytime, from which 34.55 happened at school compound. The majority of school children (66.5\%) put the blame on the perpetrators of violence, and some other attributed it to the community. Gender difference was not considered as an important issue in exposing children to violence by $58 \%$ of the respondents and gender difference is not significant predictor at the final regression model too. This finding is in line with what had been reported from else where (21).

Regarding the interpersonal relationships between the children and their parents/guardians, $58.9 \%$ had positive interactions most of the time; $64.7 \%$ always accepted and followed their parents' advice and guidance, the majority (65.2\%) always had positive and smooth interactions with their school teachers. This finding may have its own impact or implication on reducing the life time prevalence of violence in our study, without this good interaction, it could have been more than that. Different proportions for each category of interaction type were not compared due to of scarcity of published article.

In terms of awareness to existing prevention mechanisms, majority (69.2\%) claimed to have known some ways that would protect them from violence. The three most important mechanisms included; being disciplined and respectful to others; knowing where, with whom and when to move; and knowing the behavior of other person before establishing close relationships, accounting for $39.3 \%, 25.9 \%$, and $23.8 \%$, respectively. This is some what comparable with others finding. This may be due to the norm or cultural similarities on discipline and respectful behavior among study participants in different areas of Jimma especially during young age ${ }^{(6)}$. 
However, beside those mechanism that would protect them from violence, a large proportion (57.3\%) depended on strict rules and regulations to be protected from violence at school. In residential areas, $49.9 \%$ sought guarantee from patrolling police. A large majority $(81.6 \%)$ indicated that they had obtained advice from their parents or guardians as to how they could protect themselves from violence. Therefore, we can say that even if there were many protective factors, still children were under violence in different forms with high prevalence.

Predictors identified from final regression model such as educational status or child grade level, money gift from family, witnessing parental conflict, drinking any type of alcohol, and type of interaction with parents were consistently reported in other studies. However, lack of free discussion with parents and gender difference were strong predictors of violence elsewhere but not in our study. This might be due to paternalistic approach of child caring in Ethiopia considered as a norm for both sex $(9,11,19)$.

\section{Conclusion}

The prevalence of any form of violence in life time (Physical, sexual and psychological) found to be high. Of all children who experienced violence near to half of them encountered mild physical violence. Pertaining to parental relationships and interactions, the majority of the school children did not have free discussion on reproductive health issues with their parents or guardians. With regard to substance use, the study has shown less number of school children had experience of Kchat chewing and/or alcohol use. The common perpetrators of physical violence against children were found to be boyfriend/girlfriend. A large proportion of the violence against children occurred during the daytime since high proportion of physical violence reported. Regarding place of violence, the school areas take the highest. Regarding the interpersonal relationships between the children and their parents/guardians and school teachers, majority had positive interactions in most of the time; always accepted and followed their parents' advice and guidance, always had positive and smooth interactions with their school teachers. In terms of awareness, more than three-fourth claimed to have known some mechanisms that would protect them from violence. Finally, we recommend that considering predictor identified from this study would be paramount to design intervention among school children to minimize violence.

\section{List Of Abbreviations}

ACPF- African Child Policy Forum

AOR- Adjusted odds ratio

Cl-Confidence interval

OR-Odds Ratio

RH-Reproductive Health

SPSS- Statistical Package for social science

UNICEF- United Nation Children's Fund 


\section{Declarations}

\section{Ethics approval and consent to participate}

Ethical clearance and an approval letter were obtained from Jimma University institute of health-institutional reviewing board. Study participants were informed about the objective and details of the study including publication. Informed written consent obtained from each subject, and assent was obtained from their parent or care giver or legal guardian to participate in the study. Confidentiality was maintained by using anonymous codes. Ethical letter and consent form can be provided up on your request.

\section{Consent to publish}

All parties involved (Jimma University- the funding organization study subjects and authors) agreed to publish on international peer reviewed journal. During data collection, all participants informed and agreed on the major objective of the study which is for academic purpose including publication. Permission obtained for publication available with the corresponding author.

\section{Availability of data and materials}

The data sets used and/or analyzed during the current study are available from the corresponding author on reasonable request. The SPSS (software) which is completed with raw data set can be also shared. All data generated or analyzed during this study are included in this manuscript.

\section{Competing/Conflict of interest}

All authors declare that they have no any financial and non-financial competing interests. None of the authors of this paper has a financial or personal relationship with other people or organizations that could inappropriately influence or bias the content of the paper. It is to specifically state that "no competing interests are at stake and there is no conflict of interest" with other people or organizations that could inappropriately influence or bias the content of the paper.

\section{Funding}

The research was financially supported by Jimma University Institute of health.

\section{Authors' contribution}

All authors had made equal and substantial contributions to conception and design, acquisition of data, analysis and interpretation of data, prepared the manuscript critically for important intellectual content, and worked together starting from proposal development to write up. All authors read and approved the final manuscript.

Acknowledgments: The authors would like to thank

- Jimma University and Jimma university research coordinators 
- The study participants and all administrator of the selected high school (private and government)

\section{References}

1. Marian Jacobs: Children 's Institute. 2016;

2. Expert PI, Secretary-general, United Nations 2003. violence against children Contents.

3. Project T, Funded IS, The BY, Union E, Partnership IN, Unicef W. Indicators for Monitoring of VIOLENCE AGAINST CHILDREN.

4. Hyder AA, Malik FA. Violence against Children: A Challenge for Public Health in Pakistan. 2007;25(2):16878.

5. Pankhurst A, Negussie N, Mulugeta E. Understanding Children 's Experiences of Violence in Ethiopia: Evidence from Young Lives. 2016;(November).

6. Bekele I, Zewde W, Neme A. Assessment of Prevalence, Types and Factors Associated with Adolescent Sexual Abuse in High School in Limmu Gnet High School. Heal Sci J. 2017;11(3):0-7.

7. Black C. Seven Strategies for Ending Violence Against Children. 2016;

8. Cappa C. Global Statistics on Children's Protection from Violence, Exploitation and Abuse. Unicef Data [Internet]. 2014; Available from: https://data.unicef.org/resources/global-statistics-childrens-protectionviolence-exploitation-abuse/\%0Awww.cpmerg.org.

9. Sambo DL. Violence Health \& Health in the WHO African Region. 2010; Available from: http://www.afro.who.int/en/clusters-a-programmes/dpc/mental-health-violence-and-injuries/mvipublications.html

10. Tolessa Bekele WD. Experience of Sexual Coercion and Associated Factors among Female Students of Ambo University in Ethiopia. Sci J Public Heal. 2014;2(6):532.

11. Iliyasu Z, Abubakar IS, Aliyu MH, Galadanci HS, Salihu HM. Prevalence and correlates of gender-based violence among female university students in Northern Nigeria. Afr J Reprod Health [Internet]. 2011;15(3):111-9. Available from: http://www.ncbi.nlm.nih.gov/pubmed/22574498

12. Chinawa JM, Aronu AE, Chukwu BF, Obu HA. Prevalence and pattern of child abuse and associated factors in four secondary institutions in Enugu, Southeast Nigeria. Eur J Pediatr [Internet]. 2014 Apr;173(4):451-6. Available from: https://doi.org/10.1007/s00431-013-2191-4

13. Panganai T, Samkange W. Sexual Dilemma: Perceptions and Attitudes of Sexually Violated Women in Gweru Urban, Zimbabwe. Greener J Soc Sci. 2013;3(7):349-63.

14. Mullu G. Prevalence of Gender Based Violence and Associated Factors among Female Students of Menkorer High School in Debre Markos Town, Northwest Ethiopia. Sci J Public Heal. 2015;3(1):67.

15. Ahmed H. Addis Ababa University. Cah d'études africaines. 2006;46(182):291-312.

16. Worku A, Addisie M. Sexual violence among female high school students in Debark, north west Ethiopia. East African Medical Journal. 2002. p. 96-9.

17. Shimekaw B, Megabiaw B, Alamrew Z. Prevalence and associated factors of sexual violence among private college female students in Bahir Dar city, North Western Ethiopia. Health (Irvine Calif). 2013;05(06):1069-75.

18. Kisanga F. Child sexual abuse in urban Tanzania: Possibilities and barriers for prevention. 2012. 1-69 p. 
19. Mekuria A, Nigussie A, Abera M. Childhood sexual abuse experiences and its associated factors among adolescent female high school students in Arbaminch town, Gammo Goffa zone, Southern Ethiopia: a mixed method study. BMC Int Health Hum Rights. 2015;15(1):30-3.

20. Jemal J. The child sexual abuse epidemic in addis ababa: some reflections on reported incidents, psychosocial consequences and implications. Ethiop J Health Sci [Internet]. 2012;22(1):59-66. Available from:

http://www.ncbi.nlm.nih.gov/pubmed/22984332\%0Ahttp://www.pubmedcentral.nih.gov/articlerender.fcgi? artid=PMC3437980

21. Cafo JM. Assessment of Sexual Violence and Associated Factors among High School Students in Harari Regional State, Harar Town, Eastern Ethiopia. Sci Res. 2015;2(5):91.

\section{Tables}


Table 1:

Socio-demographic characteristics of respondents, Jimma Town secondary schools, Southwest Ethiopia, February 15-30, 2018

\begin{tabular}{|c|c|}
\hline Variable & Frequency(\%) \\
\hline \multicolumn{2}{|l|}{ Sex } \\
\hline Female & $241(57.5)$ \\
\hline Male & $178(42.5)$ \\
\hline \multicolumn{2}{|l|}{ Age } \\
\hline $10-14$ years & $31(7.4 \%)$ \\
\hline 15-19 years & 388(92.6) \\
\hline \multicolumn{2}{|l|}{ Ethnicity } \\
\hline Oromoo & $236(56.3)$ \\
\hline Amhara & $94(22.4)$ \\
\hline Kaffa & $27(6.4)$ \\
\hline Dawuro & $26(6.2)$ \\
\hline Tigre & $21(5)$ \\
\hline Other & 15(3.6) \\
\hline \multicolumn{2}{|l|}{ Religion } \\
\hline Orthodox & $211(50.4)$ \\
\hline Muslim & $122(29.1)$ \\
\hline Protestant & $72(12.9)$ \\
\hline Others & $12(9.2)$ \\
\hline \multicolumn{2}{|l|}{ Child grade } \\
\hline Grade 9 & $226(53.9)$ \\
\hline Grade10 & $193(46.1)$ \\
\hline \multicolumn{2}{|l|}{ Place of residence } \\
\hline Urban & 392(93.6) \\
\hline Rural & $27(6.4)$ \\
\hline \multicolumn{2}{|l|}{ Average score } \\
\hline Poor & 15(3.6) \\
\hline Fair/Satisfactory & 74(17.7) \\
\hline
\end{tabular}




\begin{tabular}{|c|c|}
\hline Variable & Frequency(\%) \\
\hline Good & $91(21.7)$ \\
\hline Very good & 132(31.5) \\
\hline Excellent & $107(25.5)$ \\
\hline \multicolumn{2}{|l|}{ Marital/r/n ship } \\
\hline Boy/girl friend & $17(4.1)$ \\
\hline Cohabiting & $94(22.4)$ \\
\hline Single/no relation & $302(72.1)$ \\
\hline \multicolumn{2}{|c|}{ Education of boy/girl friend } \\
\hline Illiterate & $10(8.7)$ \\
\hline Literate & 105(91.3) \\
\hline \multicolumn{2}{|l|}{ Grade level } \\
\hline $1-8$ & $32(30.5)$ \\
\hline $9-10$ & $31(29.5)$ \\
\hline $11-12$ & $29(27.6)$ \\
\hline $12+$ & $13(12.4)$ \\
\hline \multicolumn{2}{|l|}{ Parental r/n Ship } \\
\hline Living together & $326(77.8)$ \\
\hline Divorced & $47(11.2)$ \\
\hline Father not alive & $23(5.5)$ \\
\hline Mother not alive & $11(2.6)$ \\
\hline Both not alive & $12(2.9)$ \\
\hline \multicolumn{2}{|l|}{ Father education } \\
\hline Literate & $346(82.6)$ \\
\hline Illiterate & $26(6.2)$ \\
\hline I don't know & $47(11.2)$ \\
\hline \multicolumn{2}{|c|}{ Literate father grade } \\
\hline $1-8$ & $57(16.5)$ \\
\hline $9-10$ & $78(22.5)$ \\
\hline $11-12$ & $79(22.8)$ \\
\hline
\end{tabular}




\begin{tabular}{|ll|}
\hline Variable & Frequency(\%) \\
\hline $12+$ & $132(38.2)$ \\
\hline Mother education & \\
\hline Literate & $346(82.6)$ \\
\hline Illiterate & $34(8.1)$ \\
\hline I don't know & $39(9.3)$ \\
\hline Mothers grade & \\
\hline $1-8$ & $74(21.4)$ \\
\hline $9-10$ & $161(46.5)$ \\
\hline $11-12$ & $40(11.6)$ \\
\hline $12+$ & $71(20.5)$ \\
\hline Enough money from family & \\
\hline Yes & $309(73.7)$ \\
\hline No & $110(26.3)$ \\
\hline
\end{tabular}


Table 2:

Experiences of children with regard to different forms of violence, Jimma Town Secondary schools, Southwest

Ethiopia, February 15-30, 2018

\begin{tabular}{|ll|}
\hline Variables & Frequency (\%) \\
\hline Any form of violence & \\
\hline Yes & $262(62.5)$ \\
\hline No & $157(37.5)$ \\
\hline Mild sexual violence & \\
\hline Yes & $54(12.9)$ \\
\hline No & $365(87.1)$ \\
\hline Severe sexual violence & \\
\hline Yes & $33(7.9)$ \\
\hline No & $386(92.1)$ \\
\hline Mild physical violence & \\
\hline Yes & $195(46.5)$ \\
\hline No & $224(53.5)$ \\
\hline Severe physical violence & \\
\hline Yes & $59(14.1)$ \\
\hline No & $360(85.9)$ \\
\hline Psychological or emotional violence & \\
\hline Yes & \\
\hline No & \\
\hline
\end{tabular}


Table 3:

The child's history of substance use and the attributes of family behaviors, Jimma Town Secondary schools, Southwest Ethiopia, February 15-30, 2018

\begin{tabular}{|c|c|}
\hline Variables & Frequency (\%) \\
\hline \multicolumn{2}{|c|}{ Free discussion on $\mathrm{RH}$ issues with parents } \\
\hline Yes & 141(33.7) \\
\hline No & $278(66.3)$ \\
\hline \multicolumn{2}{|c|}{ Level of family control } \\
\hline Tight & $216(51.6)$ \\
\hline Medium & $176(42.0)$ \\
\hline Loose & $27(6.4)$ \\
\hline \multicolumn{2}{|c|}{ Witness parental conflict at home } \\
\hline Yes & $115(27.4)$ \\
\hline No & $304(72.6)$ \\
\hline \multicolumn{2}{|l|}{ Ever chewed chat } \\
\hline Yes & $47(11.2)$ \\
\hline No & $372(88.8)$ \\
\hline \multicolumn{2}{|c|}{ Ever smoke cigarettes } \\
\hline Yes & $25(6.0)$ \\
\hline No & $394(94.0)$ \\
\hline \multicolumn{2}{|c|}{ Frequency of smoke } \\
\hline Daily & $14(56.0)$ \\
\hline Every other day & $2(8.0)$ \\
\hline Once per week & $4(16.0)$ \\
\hline Once per month & $5(20.0)$ \\
\hline \multicolumn{2}{|c|}{ Ever drunk alcohol } \\
\hline Yes & 74(17.7) \\
\hline No & $345(82.3)$ \\
\hline \multicolumn{2}{|c|}{ Frequency of drunk } \\
\hline Daily & $26(35.1)$ \\
\hline
\end{tabular}




\begin{tabular}{|ll|}
\hline Variables & Frequency (\%) \\
\hline Not daily & $48(64.9)$ \\
\hline Ever got drunk & \\
\hline Yes & $30(53.6)$ \\
\hline No & $26(46.4)$ \\
\hline Used drug(shisha, Marijuana and other) & \\
\hline Yes & $20(4.8)$ \\
\hline No & $399(95.2)$ \\
\hline Frequency of using drugs & $11(55.0)$ \\
\hline Daily & $9(45.0)$ \\
\hline Not daily & \\
\hline
\end{tabular}


Table 4:

Perpetrators of Violence against Children and Related Variables, Jimma Town Secondary schools, Southwest Ethiopia, February 15-30, 2018

\begin{tabular}{|c|c|}
\hline Variables & Frequency(\%) \\
\hline \multicolumn{2}{|c|}{ Faced any physical violence who did that? } \\
\hline Family member & $40(22.2)$ \\
\hline Student & 24(13.3) \\
\hline Boy/girl friend & $51(28.3)$ \\
\hline Stranger & $17(9.4)$ \\
\hline Teacher & $42(23.3)$ \\
\hline other & $6(3.3)$ \\
\hline \multicolumn{2}{|c|}{ Faced any psychological/emotional violence,who did that? } \\
\hline Family member & $32(16.7)$ \\
\hline Student & $20(10.4)$ \\
\hline Boy/girl friend & $41(21.4)$ \\
\hline Stranger & $19(9.9)$ \\
\hline Teacher & $73(38.0)$ \\
\hline Other & $7(3.6)$ \\
\hline \multicolumn{2}{|c|}{ Ever faced any sexual violence who did that? } \\
\hline Family member & $20(14.4)$ \\
\hline Student & $13(9.4)$ \\
\hline Boy/girl friend & $49(35.3)$ \\
\hline Stranger & $16(11.5)$ \\
\hline Teacher & $36(25.9)$ \\
\hline Other & $5(3.6)$ \\
\hline \multicolumn{2}{|c|}{ Time of day you encounter any violence? } \\
\hline Day & $82(41.0)$ \\
\hline Night & $56(28.0)$ \\
\hline Both times & $62(31.0)$ \\
\hline \multicolumn{2}{|c|}{ Place mostly faced violence } \\
\hline School & $69(34.5)$ \\
\hline
\end{tabular}




\begin{tabular}{|l|l|}
\hline Variables & Frequency(\%) \\
\hline Home & $48(24.0)$ \\
\hline On road & $65(32.5)$ \\
\hline Recreational areas & $14(7.0)$ \\
\hline Other & $4(2.0)$ \\
\hline Who do you think is responsible for the violence & \\
\hline Yourself & $30(15.0)$ \\
\hline perpetrators & $133(66.5)$ \\
\hline Community & $29(14.5)$ \\
\hline Other & $8(4.0)$ \\
\hline Gender difference be a basic reason for the violence & \\
\hline Yes & $84(42.0)$ \\
\hline No & $116(58.0)$ \\
\hline Type of interaction do you have with your parents/guardians & \\
\hline Frequent disagreement and quarrel & $52(12.4)$ \\
\hline Occasional disagreement and quarrel & $72(17.2)$ \\
\hline Disagreement and quarrel happen seldom & $48(11.5)$ \\
\hline Most of the time they have positive interactions & $247(58.9)$ \\
\hline Reaction to the advice of your parents & \\
\hline Always accept and follow & $271(64.7)$ \\
\hline Sometimes reject them & $71(16.9)$ \\
\hline Always reject them & $12(2.9)$ \\
\hline I reject them seldom & $65(15.5)$ \\
\hline Type of interaction you have with your school teachers & \\
\hline Always positive and smooth & $27(22.7)$ \\
\hline Always negative and rocky & \\
\hline Sometimes negative and rocky & \\
\hline Neither positive nor negative interactions & \\
\hline
\end{tabular}


Table 5:

Existing prevention mechanism of violence against children, Jimma Town Secondary schools, Southwest Ethiopia, February 15-30, 2018

\begin{tabular}{|c|c|}
\hline Variable & Frequency (\%) \\
\hline \multicolumn{2}{|l|}{ Any mechanisms help to prevent violence against children } \\
\hline Yes & $290(69.2)$ \\
\hline No & $129(30.8)$ \\
\hline \multicolumn{2}{|l|}{ What are the mechanisms you know: } \\
\hline Be disciplined and respectful & $114(39.3)$ \\
\hline Knowing behavior of persons before establishing relationship & $69(23.8)$ \\
\hline Knowing where, with whom and when to go & $75(25.9)$ \\
\hline Resistance to peer pressure & $23(7.9)$ \\
\hline Other & $9(3.1)$ \\
\hline \multicolumn{2}{|l|}{ Who will come immediately if any violence happens to you } \\
\hline Police & $46(11.0)$ \\
\hline Family members & $203(48.4)$ \\
\hline Friends & $65(15.5)$ \\
\hline Teachers & $10(2.4)$ \\
\hline Any person in the near by & $76(18.1)$ \\
\hline Other & $19(4.5)$ \\
\hline \multicolumn{2}{|l|}{ Which prevention ways exist in your school } \\
\hline Strict rules and regulations & $240(57.3)$ \\
\hline Patrolling police & $55(13.1)$ \\
\hline Parents and Teachers Committee or Team & $84(20.0)$ \\
\hline Gender office & $27(6.4)$ \\
\hline Other & $13(3.1)$ \\
\hline \multicolumn{2}{|l|}{ Which prevention ways exist in your residential area } \\
\hline Patrolling Police & 209(49.9) \\
\hline Kebele Militia Force & $91(21.7)$ \\
\hline Community Leaders & $105(25.1)$ \\
\hline Others & $14(3.3)$ \\
\hline
\end{tabular}




\begin{tabular}{|lc|}
\hline Variable & Frequency (\%) \\
\hline Parents react aggressively if violence happens to you & \\
\hline Yes & $263(62.8)$ \\
\hline No & $156(37.2)$ \\
\hline Parents give you advice on ways of preventing violence & $342(81.6)$ \\
\hline Yes & $77(18.4)$ \\
\hline No
\end{tabular}


Table 6:

Factors associated with violence among children in secondary schools, Jimma Town, Southwest Ethiopia, February 15-30, 2018

\begin{tabular}{|c|c|c|c|c|c|}
\hline \multirow[t]{2}{*}{ Variable with category } & & \multicolumn{2}{|c|}{$\begin{array}{l}\text { Encountered any form } \\
\text { of Violence }\end{array}$} & \multirow[t]{2}{*}{$\begin{array}{l}\text { Crude } \\
\text { OR(95\% Cl })\end{array}$} & \multirow[t]{2}{*}{$\operatorname{AOR}(95 \% \mathrm{Cl})$} \\
\hline & & Yes (\%) & No (\%) & & \\
\hline \multirow[t]{2}{*}{ Gender } & Male & $120(45.5)$ & $58(36.9)$ & 1 & 1 \\
\hline & Female & $142(54.2)$ & $99(63.1)$ & $\begin{array}{l}1.442(.962, \\
2.163)\end{array}$ & \\
\hline \multirow{5}{*}{$\begin{array}{l}\text { Educational } \\
\text { achievement average } \\
\text { Score }\end{array}$} & Poor & $13(5)$ & 2(1.3) & $\begin{array}{l}0.291(.062 \\
1.359)\end{array}$ & \\
\hline & Fair/ satisfactory & $46(17.6)$ & 28(17.8) & $\begin{array}{l}1.152(.622, \\
2.132)\end{array}$ & \\
\hline & Good & $53(20.2)$ & $38(24.2)$ & $\begin{array}{l}1.356(.762 \\
2.414)\end{array}$ & \\
\hline & V.good & $80(30.5)$ & $52(33.1)$ & $\begin{array}{l}1.230(.724 \\
2.089)\end{array}$ & \\
\hline & Excellent & $70(26.7)$ & $37(23.6)$ & 1 & 1 \\
\hline \multirow{3}{*}{$\begin{array}{l}\text { Fathers' educational } \\
\text { status (from child } \\
\text { response) }\end{array}$} & Literate & $206(78.6)$ & 140(89.2) & 1 & 1 \\
\hline & Illiterate & $16(6.1)$ & $10(6.4)$ & $\begin{array}{l}0.920(.406 \\
2.085)\end{array}$ & $\begin{array}{l}2.827 \\
(1.173 \\
6.8140 *\end{array}$ \\
\hline & I don't know & $40(15.3)$ & $7(4.5)$ & $\begin{array}{l}0.258 \\
(.112, .591)\end{array}$ & $\begin{array}{l}4.223 \\
(1.242 \\
14.356)^{*}\end{array}$ \\
\hline \multirow{3}{*}{$\begin{array}{l}\text { Mothers' educational } \\
\text { status }\end{array}$} & Literate & 209(79.8) & 137(87.3) & 1 & 1 \\
\hline & Illiterate & $26(9.9)$ & $8(5.1)$ & $\begin{array}{l}0.469(.206 \\
1.067)\end{array}$ & \\
\hline & I don't know & $27(10.3)$ & 12(7.6) & $\begin{array}{l}0.678(.332 \\
1.384)\end{array}$ & \\
\hline \multirow[t]{2}{*}{ Money gift from Family } & Yes & $174(66.4)$ & 135(86.0) & 1 & 1 \\
\hline & No & 88(33.6) & $22(14.0)$ & $\begin{array}{l}3.103 \\
(1.848 \\
5.212)^{\star}\end{array}$ & $\begin{array}{l}2.345 \\
(1.297 \\
4.239)^{\prime}\end{array}$ \\
\hline \multirow{2}{*}{$\begin{array}{l}\text { Educational status } \\
\text { (Child grade) }\end{array}$} & Grade 9 & $148(56.5)$ & $78(49.7)$ & 1 & 1 \\
\hline & Grade 10 & $114(43.5)$ & $79(50.3)$ & $\begin{array}{l}0.761(.511 \\
1.131)\end{array}$ & \\
\hline \multirow[t]{2}{*}{ Level of family control } & Tight & 133(50.8) & $83(52.9)$ & 1 & 1 \\
\hline & Medium & $107(40.8)$ & $69(43.9)$ & $\begin{array}{l}1.033(.687 \\
1.554)\end{array}$ & \\
\hline
\end{tabular}




\begin{tabular}{|c|c|c|c|c|c|}
\hline & Loose & $22(8.4)$ & $5(3.2)$ & $\begin{array}{l}0.364(.133 \\
.999)\end{array}$ & \\
\hline \multirow[t]{2}{*}{$\begin{array}{l}\text { Witnessing family } \\
\text { conflict }\end{array}$} & Yes & $93(35.5)$ & $22(14)$ & $\begin{array}{l}0.296(.177 \\
.497) \star\end{array}$ & $\begin{array}{l}0.465(.266, \\
.813)^{\star \star}\end{array}$ \\
\hline & No & $169(64.5)$ & $135(86)$ & 1 & 1 \\
\hline \multirow[t]{2}{*}{ Ever kchat chewing } & Yes & $41(15.6)$ & $6(3.8)$ & $\begin{array}{l}0.214(.089 \\
.517)^{\star}\end{array}$ & $\begin{array}{l}.466 \\
(.180,1.208)\end{array}$ \\
\hline & No & $221(84.4)$ & $151(96.2)$ & 1 & 1 \\
\hline \multirow[t]{2}{*}{ Ever drunk any alcohol } & Yes & $61(23.3)$ & $13(8.3)$ & $\begin{array}{l}0.297(.158 \\
0.562)\end{array}$ & $\begin{array}{l}0.470(.234, \\
.945)^{*}\end{array}$ \\
\hline & No & $201(76.7)$ & 144(91.7) & 1 & 1 \\
\hline \multirow[t]{2}{*}{ Parental advice } & Yes & $207(90)$ & $135(86)$ & 1 & 1 \\
\hline & No & $55(21)$ & $22(14)$ & $\begin{array}{l}0.613 \\
(.357,1.052)\end{array}$ & \\
\hline \multirow[t]{4}{*}{$\begin{array}{l}\text { Interaction with } \\
\text { parents/guardian }\end{array}$} & $\begin{array}{l}\text { Frequent } \\
\text { disagreement and } \\
\text { quarrel }\end{array}$ & $41(15.6)$ & $11(7)$ & $\begin{array}{l}.293(.144 \\
.597) \star\end{array}$ & $\begin{array}{l}0.575(.263, \\
1.260)\end{array}$ \\
\hline & $\begin{array}{l}\text { Occasional } \\
\text { disagreement and } \\
\text { quarrel }\end{array}$ & $58(22.1)$ & $14(8.9)$ & $\begin{array}{l}.264(.140 \\
.498) \star\end{array}$ & $\begin{array}{l}0.393(.201 \\
.768)^{\star}\end{array}$ \\
\hline & $\begin{array}{l}\text { Disagreement and } \\
\text { quarrel happen } \\
\text { seldom }\end{array}$ & $34(13)$ & $14(8.9)$ & $\begin{array}{l}.450(.230 \\
.880)^{\star}\end{array}$ & $\begin{array}{l}0.522(.256, \\
1.065)\end{array}$ \\
\hline & $\begin{array}{l}\text { Most of the time they } \\
\text { have positive } \\
\text { interactions }\end{array}$ & $\begin{array}{l}129 \\
(49.2)\end{array}$ & $\begin{array}{l}118 \\
(75.2)\end{array}$ & 1 & 1 \\
\hline \multirow[t]{4}{*}{$\begin{array}{l}\text { Interaction with school } \\
\text { teachers }\end{array}$} & $\begin{array}{l}\text { Always positive and } \\
\text { smooth }\end{array}$ & $\begin{array}{l}166 \\
(63.4)\end{array}$ & $\begin{array}{l}107 \\
(68.2)\end{array}$ & 1 & 1 \\
\hline & $\begin{array}{l}\text { Always negative and } \\
\text { rocky }\end{array}$ & $30(11.5)$ & $11(7)$ & $\begin{array}{l}.569(.273, \\
1.183)\end{array}$ & \\
\hline & $\begin{array}{l}\text { Sometimes negative } \\
\text { and rocky }\end{array}$ & $6(2.3)$ & $4(2.5)$ & $\begin{array}{l}1.034(.285 \\
3.751)\end{array}$ & \\
\hline & $\begin{array}{l}\text { I have neither positive } \\
\text { nor negative } \\
\text { interactions }\end{array}$ & $60(22.9)$ & $35(22.3)$ & $\begin{array}{l}.905(.559 \\
1.466)\end{array}$ & \\
\hline \multirow[t]{4}{*}{ Parental relationship } & Living together & 192(73.3) & $\begin{array}{l}134 \\
(85.4)\end{array}$ & 1 & 1 \\
\hline & Divorced & $38(14.5)$ & $9(5.7)$ & $\begin{array}{l}0.339(.159, \\
.725) *\end{array}$ & \\
\hline & Father not alive & $15(5.7)$ & $8(5.1)$ & $\begin{array}{l}.764(.315, \\
1.853)\end{array}$ & \\
\hline & Mother not alive & $8(3.1)$ & $3(1.9)$ & .537 (.140, & \\
\hline
\end{tabular}




$\begin{array}{llll}\text { Both parents not alive } \quad 9(3.4) & 3(1.9) & .478(.127, \\ 1.797)\end{array}$

$*_{\text {-P-value }}<0.05,{ }^{*}$-P-value $<0.01$, Hosmer and Lemeshow test $(P$-value-0.756) 